\title{
THE INTONATION OF MITIGATING POLITENESS IN CATALAN
}

\author{
Empar Devís Herraiz \& Francisco José Cantero Serena \\ Applied Phonetics Laboratory - University of Barcelona \\ devis@ub.edu , cantero@ub.edu
}

\section{Resumen}

En este trabajo presentamos un modelo descriptivo de los rasgos melódicos de la cortesía atenuadora en catalán, a partir del análisis acústico de un corpus de habla espontánea y su posterior validación perceptiva. El modelo permite abordar el análisis pragmático del fenómeno, así como ofrecer, en el futuro, pautas para su enseñanza. Los resultados del análisis reflejan, además, el carácter amplio del fenómeno, que excede los límites estrictos del código idiomático, y permiten su análisis interlingüístico. El trabajo es fruto de la colaboración entre los proyectos de investigación Análisis melódico del habla y Fonocortesía.

Palabras clave: entonación, atenuación, cortesía, catalán.

\section{Abstract}

This paper presents a descriptive model of the melodic characteristics of expressions of politeness attenuators in Catalan, based on the acoustic analysis of a spontaneous speech corpus and its subsequent perceptive validation. The model allows the pragmatic analysis of the phenomenon to be covered, as well as offering future guidelines for its teaching. In addition, the results of the analysis reflect the extensive character of the phenomenon, which surpasses the strict limits of idiomatic code, and allows inter-linguistic analysis. The paper is the product of the collaboration between the Melodic Analysis of Speech and Fonocortesía research projects ${ }^{1}$.

Keywords: intonation, mitigation, politeness, Catalan.

\section{INTRODUCTION}

The formalised study of verbal politeness began in the 1970s and 80s with the appearance of three founding theories by: R. Lakoff (1973), G. N. Leech (1983) and P. Brown and S. Levinson (1987). The subject has given rise to enormous interest over the last few decades and in the Hispanic context a programme called EDICE $^{2}$ (Studies on the Discourse of Politeness in Spanish) has been created, which has provided knowledge regarding politeness, impoliteness and related social-cultural phenomena since 2002. EDICE is a contact network among researchers who include in their work studies of the phenomenon of politeness in the different variants of Spanish, and which to date has held five international symposiums. The programme has described the phenomenon of politeness in its different variations, recognised the social-cultural contexts that underlie behaviours of politeness in Spanish, carried out contrastive studies between the different variations of Spanish and other European variations, and has contributed to the development of alternative theory models that explain and describe

\footnotetext{
${ }^{1}$ MICINN (Spanish Ministry for Science and Innovation) Projects. Reference no.: FFI2009-13214-C02-00 and FF12009-07034, respectively.

${ }^{2}$ http://www.edice.org/
} 
the phenomenon of politeness. In the field of Catalan, however, the phenomenon has not aroused the same interest, and we only have references by Payrató (1988).

In general, the most neglected aspect in the research on the subject is that relating to the pragmatic functions of the melodies that convey politeness in conversation. The melodic component has recently been given some consideration in research on Spanish: Álvarez and Blondet (2003), Roldán (2000), Orozco (2008), Devís (2011); but in Catalan it continues to be the great forgotten area, apart from exceptions such as Payà (2003), Astruc (2008), Nadeu (2008) and Nadeu \& Prieto (2011). This paper, therefore, aims to cover the delimitation of melodic characteristics ${ }^{3}$ conducive to the creation of contextual effects of politeness (through the linguistic mechanism of verbal mitigation), with the aim of rectifying the absence of exhaustive research that provides a wide volume of data relating to the prosodic phenomenology in conversation ${ }^{4}$.

Politeness is understood as a phenomenon with values and effects on the social level of language and as a social interaction tool with strategic purposes in communication, according to the interests of the speakers. By mitigating politeness we understand, therefore, the strategies that the speaker uses to soften, as far as possible, his or her impositions or to safeguard the negative image and the self-esteem of the speaker. Attenuation is a very useful form of pragmatic-speech for mitigating the strength of a spoken assertion, expressing, for example, uncertainty when formulating a divergent opinion, presenting disagreement as a partial conformity or focussing the object of disagreement from an impersonal viewpoint (Haverkate 1994: 117). This study focuses exclusively on melodic-type strategies.

The function of attenuation at a supra-segmental level basically corresponds to intonation. For this reason melodic characteristics tend to be determinant when interpreting an utterance as being more or less polite. Authors such as Quilis (1988, 1993), Hidalgo (2001, 2006, 2007, 2009), Waltereit (2005), Haverkate (1994), Álvarez and Blondet (2003), Briz and Hidalgo (2008), and Devís (2011) have observed, for Spanish, how certain intonational forms commonly comply with a function of attenuation or mitigation in utterances that could contain a certain implicit "aggressiveness". Whereas, there is no research dedicated to melodic attenuator characteristics in Catalan.

The main objective of this research therefore focuses on presenting the melodic characteristics that reveal politeness attenuators in Catalan.

For the Fonocortesía project, the consideration of (im)politeness is assumed from two viewpoints ${ }^{5}$ :

\footnotetext{
${ }^{3}$ This means delimiting the methodology, as we will leave aside other prosodic characteristics, such as duration and intensity.

${ }^{4}$ The functioning of colloquial conversation can be explained, not as the transgression of sentence grammar, but as a set of structures and strategies, of a pragmatic nature, constituted in the interaction process (Briz and Val.Es.Co group 2002: 11), and it is precisely in this linguistically less "precise" speech situation (presence of unfinished phrases or words, communicative speed and immediacy, common vocabulary, etc), where the speaker leans most towards the paraverbal (and, of course, also non-verbal and gestural) so that his or her resulting message is fully communicative. Indeed, the main function of colloquial speech does not tend to be instrumental, but social, therefore among speakers with a close relationship and/or social equality, the melodic element becomes a communicative resource that is extremely useful in certain situations in which the purpose is mainly social (confirm, reaffirm, question, negotiate social relations, etc.).

${ }^{5}$ See Hidalgo (2009).
} 
- Extralinguistic politeness: set of social, conventional and particular rules for each society or culture that determine and control the correct behaviour of its members, and leads them to avoid certain forms of conduct, favouring others, "normally associated with a dominant model of education, manners and protocols" (Calsamiglia and Tusón, 2002: 161); politeness governs greetings, farewells, the way of addressing authorities, requesting permission to intervene in a debate, giving the floor in formal situations, etc.

- Intralinguistic or strategic politeness: conversational strategy, committed to eliminating or mitigating conflicts; in this case, speakers are interested in finding and selecting linguistic forms that best suit the maintenance of the established relationship; on the contrary, they opt for a direct or indirect breakdown of said conversational relationship. Its analysis therefore is focused on three fronts: enhancing-intensifying politeness, mitigating-attenuating politeness and impoliteness (open or direct, positive, negative and hidden, according to Alba, 2008) including their pragmatic projections (negative irony, etc.).

\section{METHODOLOGY}

In order to analyse the data, the Melodic Analysis of Speech $(A M H)^{6}$ method has been used. The starting point is the definition of intonation based on the F0 variations that comply with a linguistic function during the utterance. Intonation is considered to function on three levels:

- Prelinguistic: including the phenomena of accent, rhythm and melody, which works jointly with co-structuring phonic elements of discourse, regardless of any other significant dimension.

At this level, intonation is a linguistic "container", integrating and delimiting the units of discourse. It is what Quilis (1993) called the "delimiting function" and "integrating function" of intonation. The melodic characteristics typical of this level are very specific, phonetic characteristics.

- Linguistic: including melodic characteristics with a phonological performance that allows the functional units of intonation, their "linguistic signs", to be characterised and distinguished.

In Spanish eight contours were identified, resulting from the combination of phonologic characteristics $^{7}$ (/ \pm interrogative, \pm suspended, \pm emphatic/) that make up 4 types of intonation described by the model (neutral, interrogative, suspended and emphatic), whose melodic patterns create the typical melodies of the language ${ }^{8}$.

- Paralinguistic: including melodic variants of said contours, within the wide margins of dispersion for each of them.

\footnotetext{
${ }^{6}$ See Cantero (2002) and the collective volume Melodic Analysis of Speech (AMH): 1999-2009.

7 Phonological characteristics described at this level are abstract, merely opposing characteristics.

${ }^{8}$ See Cantero and Font-Rotchés (2007), a summary of the melodic patterns for Spanish; and Font-Rotchés (2007; 2009) for patterns for Catalan.
} 
These melodies allow specific emotions, idiolectic speech characteristics or those of the speaker's personality to be expressed, and can even be variably coded (as occurs, for example, in the expression of politeness: see Devís 2011).

The method for analysis of the three intonation levels allows:

- the intonational curve to be segmented into tonal segments (normally one tonal segment per vowel, except for inflections);

- the intonation to be analysed regardless of the other levels of linguistic analysis;

- all of the tonal phenomena of speech included in the melody (accent, rhythm and intonation) to be analysed.

It includes two phases:

Acoustic phase (descriptive):

- extraction of the F0 of the utterance;

- determination of the values of the F0 vowels. The vowels are identified and their average value is recorded;

- the succession of vowel values creates an essential melodic curve that eliminates the irrelevant values;

- finally, each melodic curve obtained in $\mathrm{Hz}$ is standardised in percentages to create an independent melody of the speaker's characteristics.

\section{Perceptive phase (experimental):}

- the resulting melody is synthesised (for example, using the Praat acoustic analysis programme) and the tonal values are replaced with standardised values;

- only the values of the melodic characteristic, whose relevance is to be verified, are modified;

- a perceptive experiment is performed, allowing the synthesised melody to be validated and/or the melodic hypothesis counter-verified.

\section{CORPUS}

The data that allowed the identification of mitigating melodic characteristics in the acoustic phase, were taken from the Oral corpus of spontaneous speech by Font-Rotchés ${ }^{9}$. In 1998 a research project was commenced at the Applied Phonetics Laboratory with the objective of describing the most relevant aspects of intonation for Catalan: the definition of its melodic patterns and their characteristics, as well as the phonological units of intonation and their dispersion margins (Font-Rotchés, 2007).

To carry this out a spontaneous speech corpus was necessary that reflected genuine authentic speech with a wide number of participants that were sufficient and varied with regard to gender, age and social-cultural and dialectal origin. In addition, it needed to be random and compensated, meaning, a balanced representation of the different participants and utterance profiles.

\footnotetext{
${ }^{9}$ See a wide sample of the corpus in Font-Rotchés (2006).
} 
Following the suggestion by Cantero (2002: 167), the spontaneous speech sample was created, based on the recording of television programmes with public participation, leaving aside other media, such as radio, in which the participants tend to have a certain level of professionalism, and therefore a language model that is not spontaneous.

20 different programmes were selected from Catalan television (TV3 and Canal 33) and the Catalan section of Spanish national television (TVE2). Between one and three editions of each programme were recorded during 1996 and 2000. During the same period, TVE2 aired 5 editions of a debate programme lasting 2 hours each, which was very apt for the objective of the corpus due to the extensive participation of anonymous people expressing their point of view on highly controversial current affairs.

The corpus of recordings totalled 47 hours of audiovisual material, aired between 1996 and 2000. The programmes contained reports, interviews, street interviews, debates, competitions, chat shows and documentary dramas, among others, in which dialogue was abundant.

To select the utterances the following criteria were taken into account:

a) genuine participants, with good vocalisation and no speech defect

b) a maximum of 8 to 10 utterances from a single participant

c) fragments selected where the participant spoke naturally

d) no overlapping of voices, music or background noise in the utterances

Based on these criteria, a total of 580 utterances comprised the definitive corpus, taken from 160 participants (98 men: 58\%; 67 women: 42\%), between the ages of 18 and 70, from very different professions: doctors, police, administrative personnel, gymnasts, finance professionals, students, judges, psychiatrists, actors, retired people, chefs, farm workers, singers, labourers, clergymen, real estate agents... and from different regions: Catalonia, Valencia and the Balearic Islands.

For each utterance a file was created containing the utterance code, location on the tape, programme, channel, day and time of the recording, the text spoken, description of the context in which it was spoken and a description of the participant.

Finally, the audio files of each utterance were taken from the video using SoundForge. A code was given to each corresponding utterance.

The utterances of the acoustic phase presented in this paper were taken from a review of the whole corpus.

\section{INTONATION OF POLITENESS ATTENUATORS IN CATALAN}

\subsection{Acoustic phase}

Following are a series of examples in which the main characteristics hypothesised as politeness attenuators can be observed. 
Each point on the curve in the graph is a representative vowel value. For the melodic analysis only the vowel values are of interest, given that the most important sound of the discourse is always the vowel. Each vowel value constitutes a tonal segment in the melody, which tends to correspond to a syllable (in the graph we can see them segmented in columns). In the first horizontal line we have the orthographic transcription. Only in cases where the duration of the vowel is significantly longer (not one but two moras in duration), can we assume that the vowel has not one but two tonal segments. In these cases, the vowel has a tonal inflection, which is defined as the succession of two (or more) tonal segments in a vowel. In Figure 1 we can see a vowel with two "no" tonal segments: the second transcribed with an asterisk. The tonal segment, therefore, is each relevant $\mathrm{F} 0$ value in the melody. We consider there to be two tonal segments when the rising or falling percentage is equal to or over $10 \%{ }^{10}$.

The second horizontal line contains the Herz values (absolute values taken from the vowels), and in the third are the percentages of rise and fall. The first value is $100 \%$-a random number- based on which the variation percentages between one segment and the next are taken, to obtain relative values: the last line shows the values of the curve standardised by the rise and fall percentages. Each graph shows this standard curve. The AMH method is always based on standardised curves because only the relativisation of each tonal value with regard to the previous value allows the melody to be constructed as is, regardless of the speaker's characteristics.

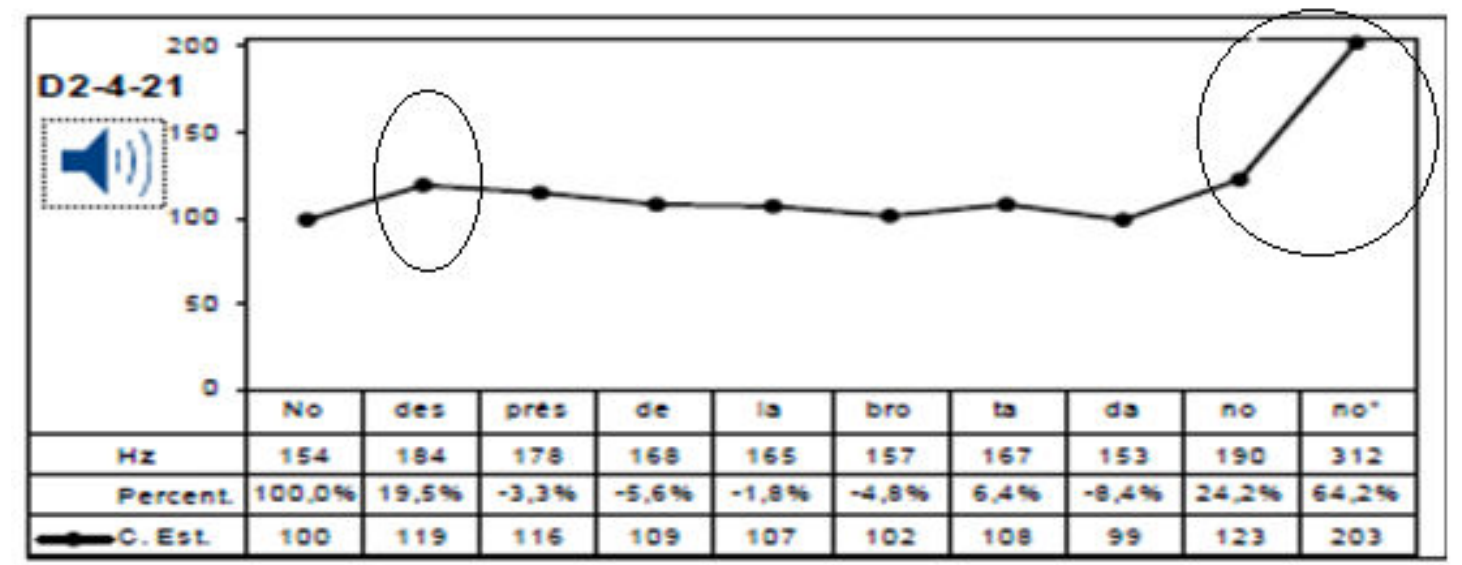

Figure 1. Standardised melody of the utterance: No, després de la brotada no (no, after the outbreak, no)

Figure 1 presents a phonic group with a very flat declination and a suspended final inflection $(+64.2 \%)$. From a linguistic intonation viewpoint ${ }^{11}$, it is therefore a /+suspended/ melody. In this context, and at a pragmatic level, it acts as an attenuating characteristic to mitigate the implicit aggressiveness of the command. This functional transposition of the /+suspended/ intonation contour, which on a pragmatic level acts as an attenuator, has previously been identified by Hidalgo (2009). The prominence of the atonic vowel of the syllable "des", from a paralinguistic intonation ${ }^{12}$ viewpoint, also becomes a relevant acoustic key for distinguishing a polite utterance from a neutral one, something recurrent in all of the examples analysed, and which causes a melodic rhythm that distinguishes and characterises politeness attenuator utterances.

\footnotetext{
${ }^{10}$ See Cantero (1999).

${ }_{11}^{11}$ By linguistic level we refer to the second level of intonation described by Cantero (2002).

12 The paralinguistic level is the third level of intonation described by Cantero (2002).
} 


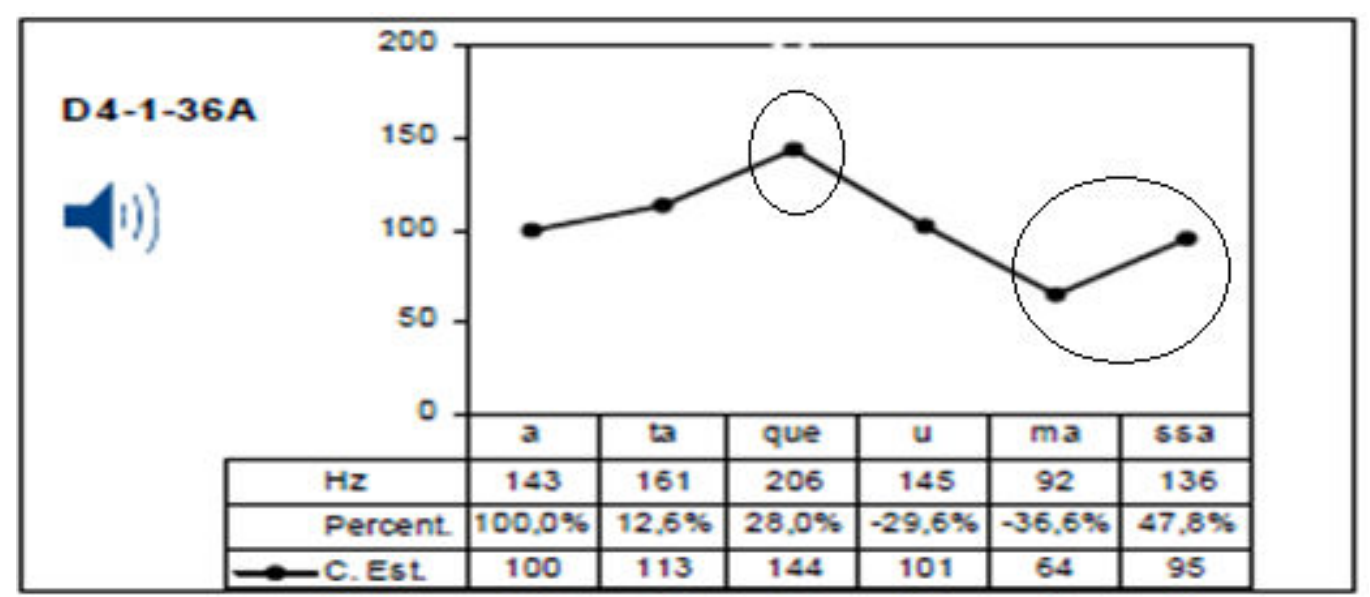

Figure 2. Standardised melody of the utterance: Ataqueu massa (you attack too much)

Figure 2 presents the same structure as the previous utterance, with a rising suspended final inflection $(+47.8 \%)$, although, in this case, with the first peak on the first tonic vowel. The reproach is softened with the rising end.

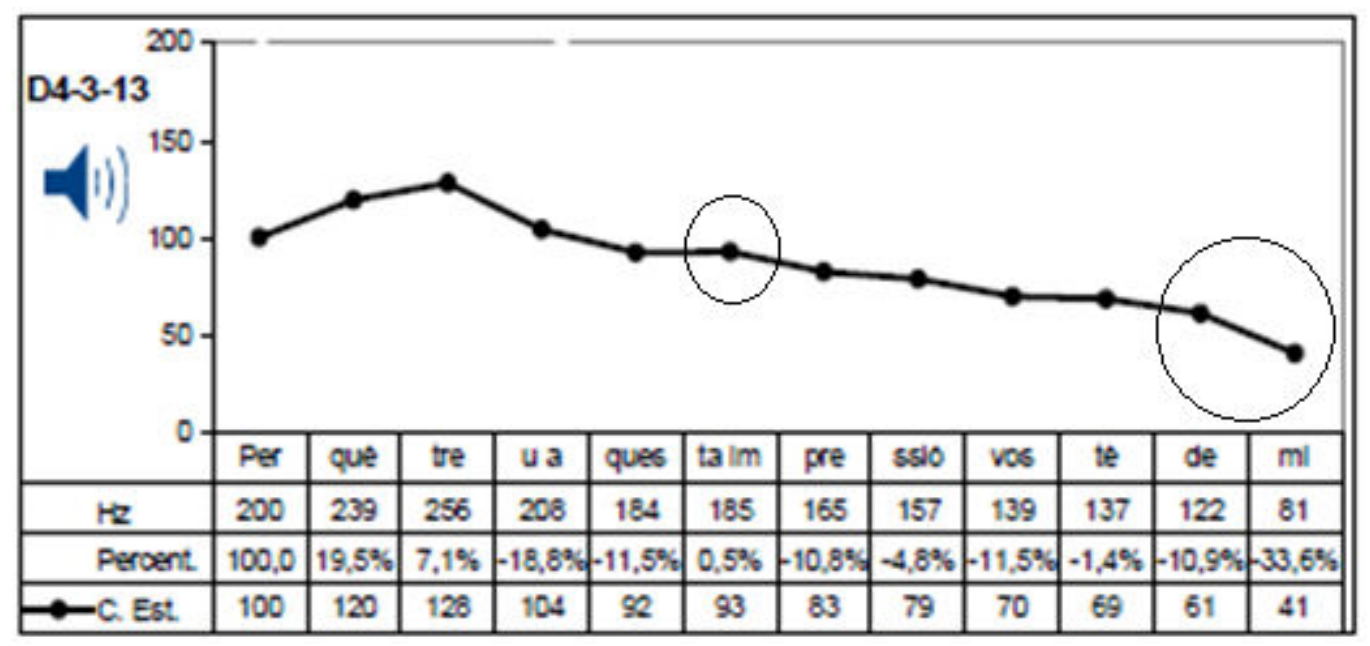

Figure 3. Standardised melody of the utterance: Per què treu aquesta impressió vostè de mi? (why do you have this impression of me?)

Figure 3 once again presents a small prominence in the atonic vowel " $t a$ ", although in this case with a falling final inflection. This type of falling inflection is highly recurrent in the mitigating utterances of the corpus. In Figure 4 the same pattern appears (prominence in the atonic and falling end). 


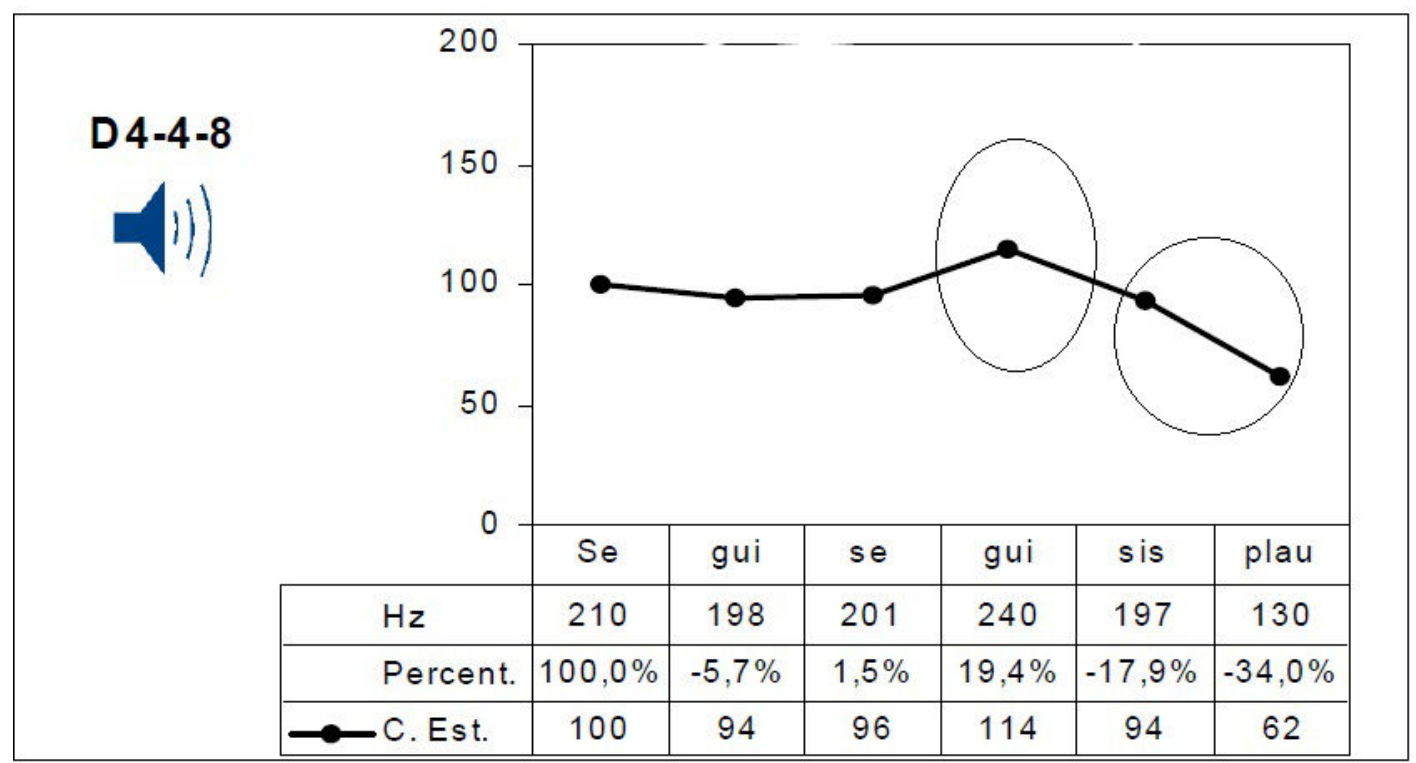

Figure 4. Standardised melody of the utterance: Segui, segui, si us plau (sit down, sit down, please)

Another characteristic frequently observed is word emphasis. In Figure 5 we can see how "defensa" is emphasised with a circumflex tonal pattern (completely breaking the declination). We can also see, again, a falling final inflection, although this time initiated from the pretonic vowel (tonal prominence of the atonic).

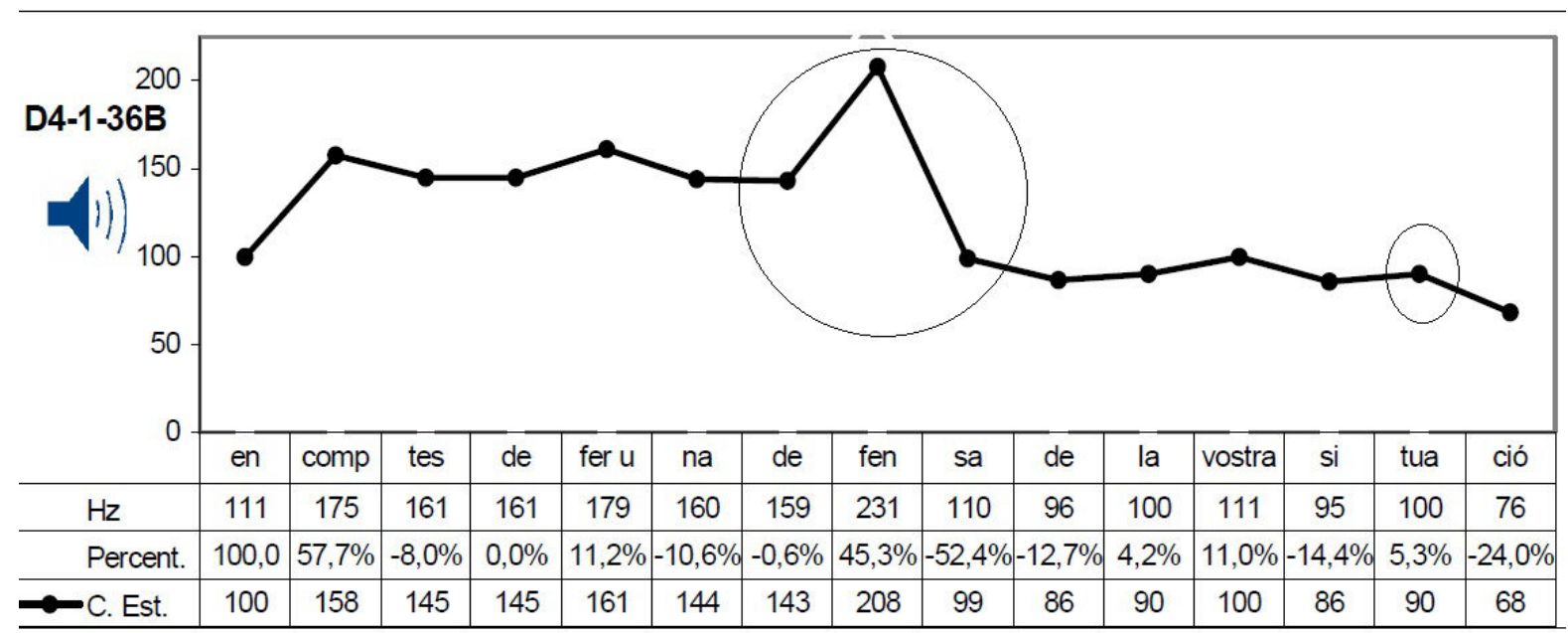

Figure 5. Standardised melody of the utterance: en comptes de fer una defensa de la vostra situació (instead of defending our situation)

Figure 6 shows an almost flat melody, with a slight declination that starts at the first peak in the post-tonic vowel (prominence of atonic) and created based on circumflex word emphasis, with a suspended end. The participant's complaint is harsh, and therefore the melodic characteristics soften this harshness. 


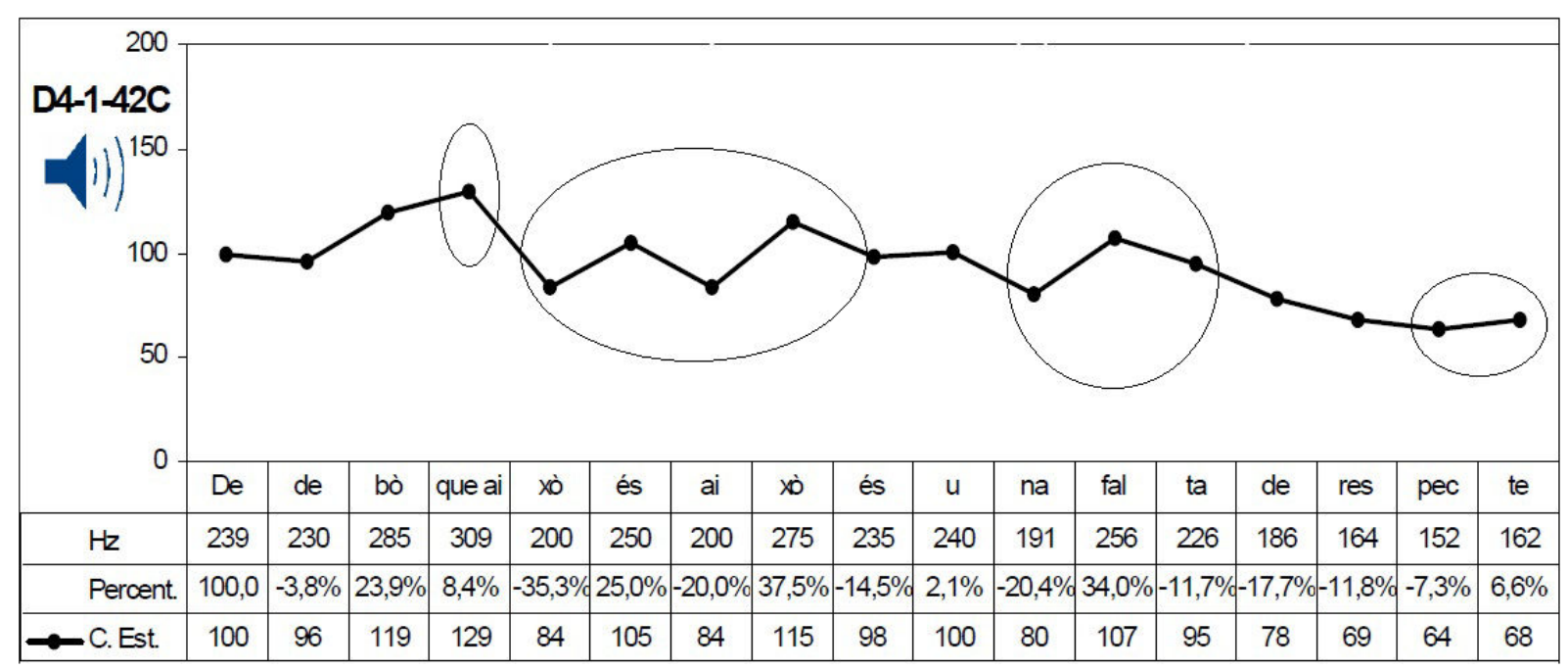

Figure 6. Standardised melody of the utterance: de debó que això és això és una falta de respecte (honestly, this is, this is a lack of respect)

Another relevant characteristic that reflects politeness is the circumflex final inflection. Figure 7 shows a first peak in the atonic and a circumflex end, which softens the command.

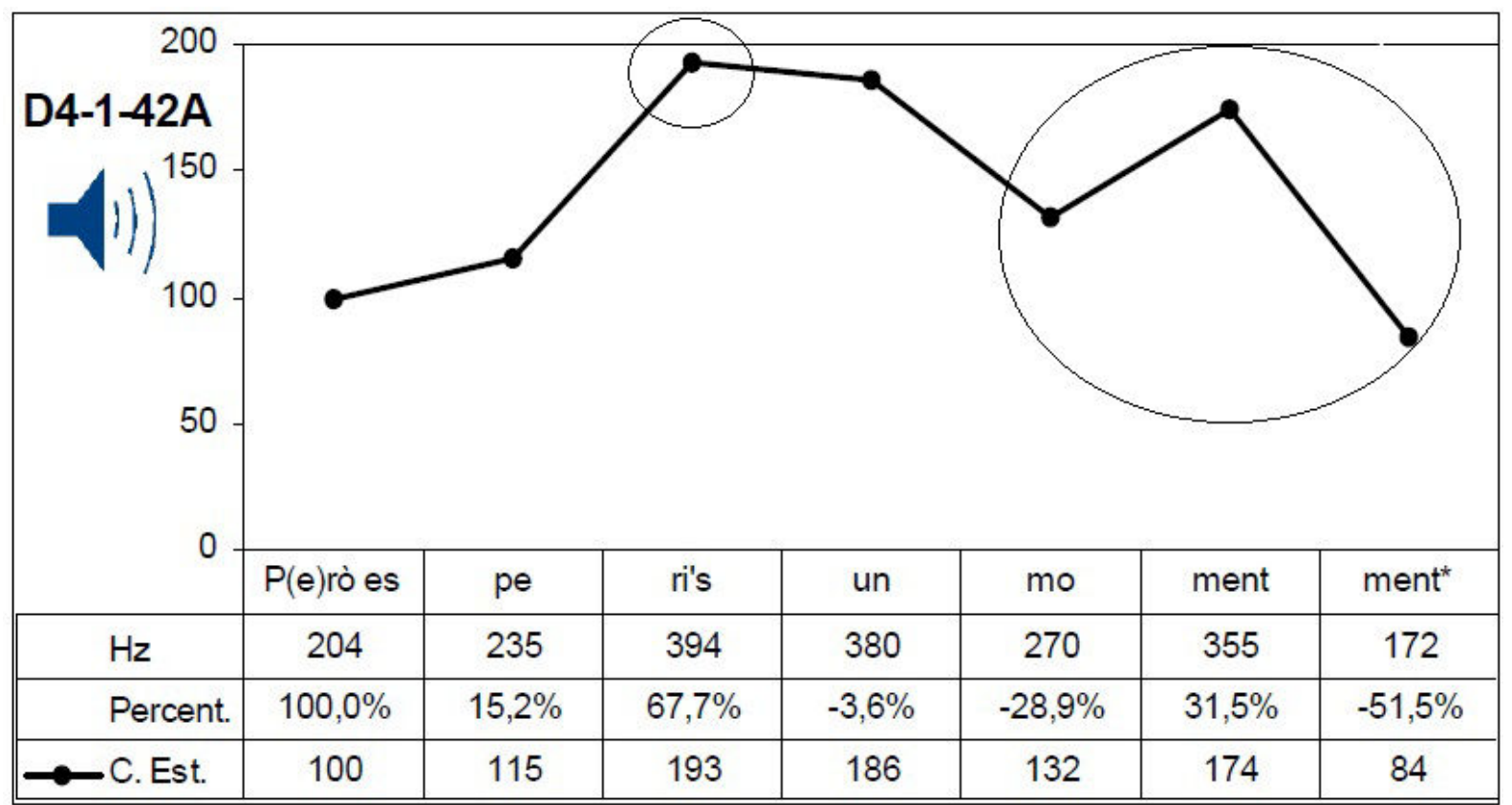

Figure 7. Standardised melody of the utterance: però esperi's un moment (but wait a moment)

The data analysed therefore, allows a series of melodic characteristics to be established that are responsible for mitigating impolite utterances or those that could hold a type of implicit lexical-grammatical aggressiveness. Based on these, the following hypothesis can be established: 
1) Final inflection:

- /+suspended/ final inflection (with a final rise between 15 and 70\%)

- Neutral final inflection (with a fall of no more than 40\%)

- Circumflex final inflection (rising falling)

2) Body of the contour:

- Prominence of atonics (with rises of no more than 30\%)

- Very flat declinations

- First peak displaced or absent

- Word emphasis (narrow focus) with circumflex inflection

These characteristics coincide, essentially, with those which in previous research (Devís, 2011) had been identified for colloquial Spanish. However, in this corpus no other characteristics that are highly relevant in Spanish appeared, such as internal inflections and interrogative final inflections. The decision was taken therefore to include the latter in the perceptive phase, in order to determine the differentiating melodic characteristics for the two languages.

\subsection{Perceptive phase}

To validate the hypothesised characteristics as politeness attenuators, a specific corpus was created, ad hoc, in which the utterances were clearly impolite from a lexical-grammatical viewpoint, in order to assure that the characteristics introduced in the exclusively melodic manipulations were those responsible for mitigating. Four insults, four commands and six confrontations were recorded ${ }^{13}$. The fourteen utterances were recorded by one man and one woman, and were later manipulated using the Praat acoustic programme.

First of all, only the final inflections were manipulated, creating 15 versions (one for each of the 14 original utterances, spoken by either a female or male voice, and one other by both). Next we manipulated only one internal characteristic (prominence of atonics, word emphasis, internal inflections...), leaving the rest of the original utterance unchanged, creating 15 more versions. Finally, we introduced combined manipulations: we took the utterance that contained an internal characteristic manipulation and added a final inflection different to the original (suspended, falling, interrogative or circumflex), creating a total of 14 combined versions.

In total we created 44 manipulated versions. Subsequently, we carried out a perceptive test, including the 14 original utterances and a manipulated version of each original. The objective was to define whether or not there was a melodic characteristic that created attenuation on its own, or if the interaction of more than one characteristic was required.

\footnotetext{
${ }^{13}$ Insults: Ets un fill de puta (you bastard), Ves-te'n a cagar (go to hell), Ets imbècil (you're an idiot), Em fas fàstic, tio (you disgust me). Commands: Tanca la porta (shut the door), Dóna'm la mà (give me your hand), Calla ja (shut up), Vine aquí (come here). Confrontations: No estic d'acord amb tu (I don't agree with you), Això és mentida (that's a lie), No em sembla bé (I don't agree), No vull tornar a veure't (I don't want to see you again), Tu et creus molt llest, però estàs completament equivocat (you think you're really clever, but you are completely wrong), No puc més, em tens fart (I can't take any more, I've had enough).
} 
Following are some of the examples of the utterances analysed and their respective manipulation.

\subsubsection{Insults}

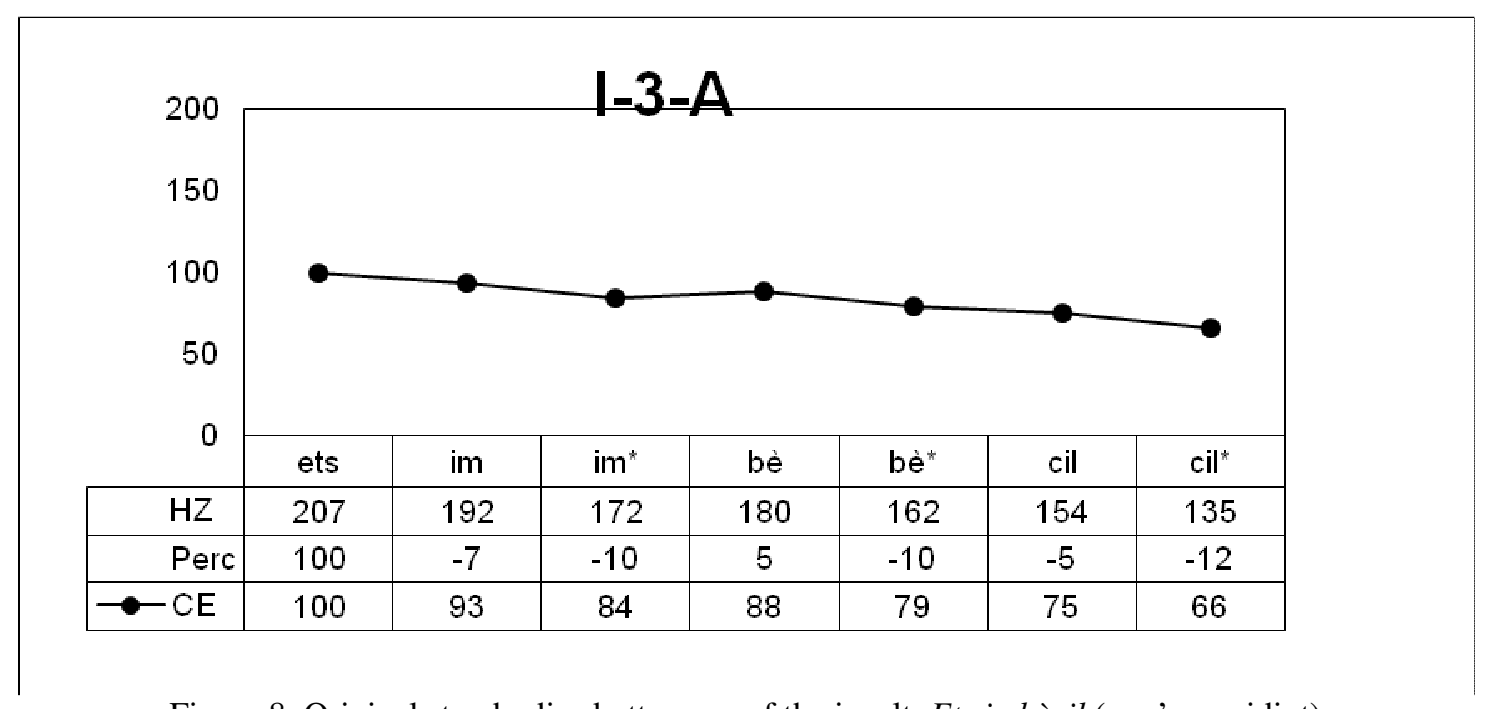

Figure 8. Original standardised utterance of the insult: Ets imbècil (you're an idiot)

Figure 8 shows one of the utterances created ad hoc for its subsequent manipulation, in which we can see a flat declination with a rising final inflection.

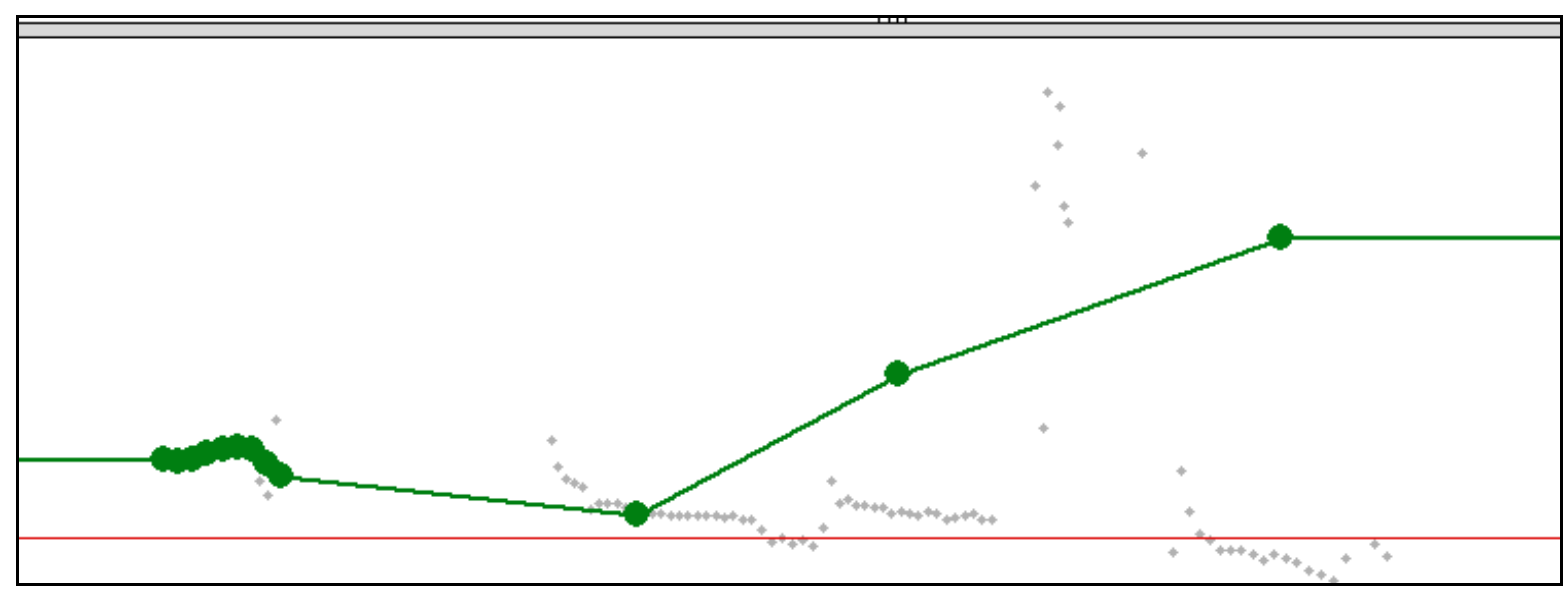

Figure 9. Manipulation of the same utterance with an interrogative final inflection

Figure 9 shows the manipulation of the same original utterance, incorporating an interrogative final inflection and leaving the rest of the utterance unchanged. The final inflection begins on the last tonic vowel until the end of the utterance (imbècil). 


\subsubsection{Confrontations}

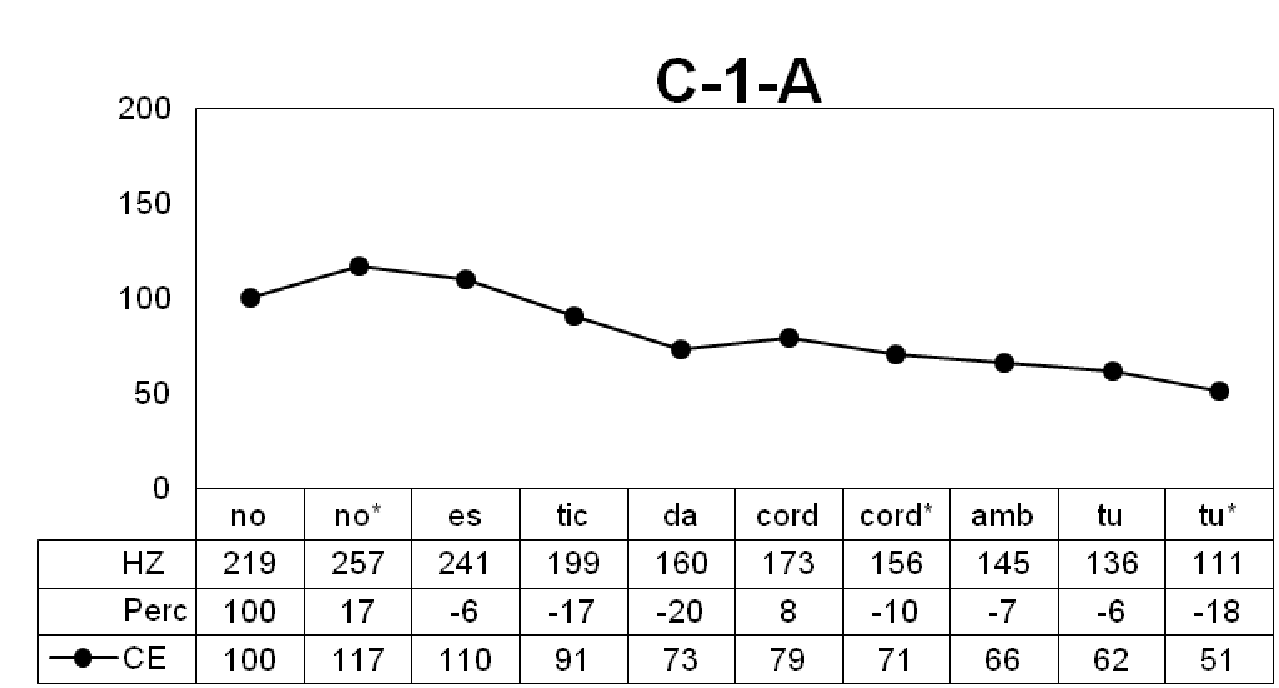

Figure 10. Original standardised utterance of the confrontation: No estic d'acord amb tu (I don't agree with you)

Figure 10 shows the original utterance relating to a confrontation.

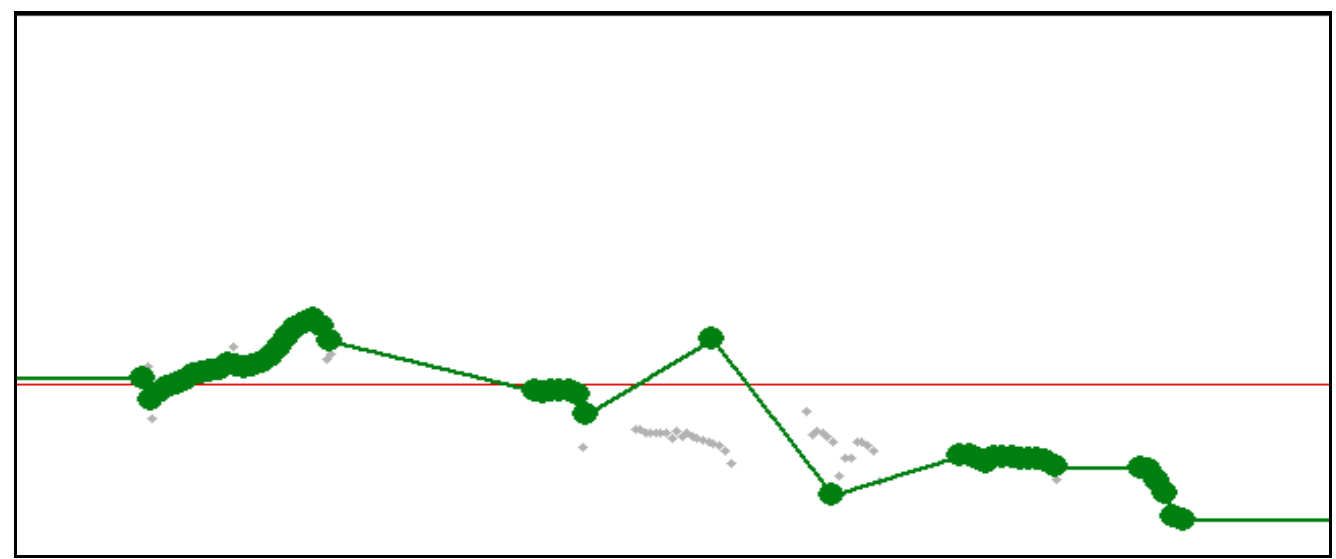

Figure 11. Manipulation of the same utterance with prominence of an atonic vowel

Figure 11 shows the manipulation of the previous original utterance. In this case only the F0

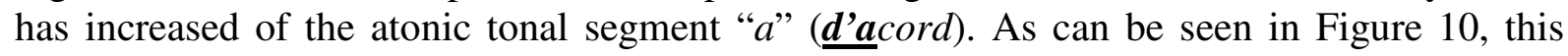
tonal segment had an F0 inferior to the tonic that preceded it. 


\subsubsection{Commands}

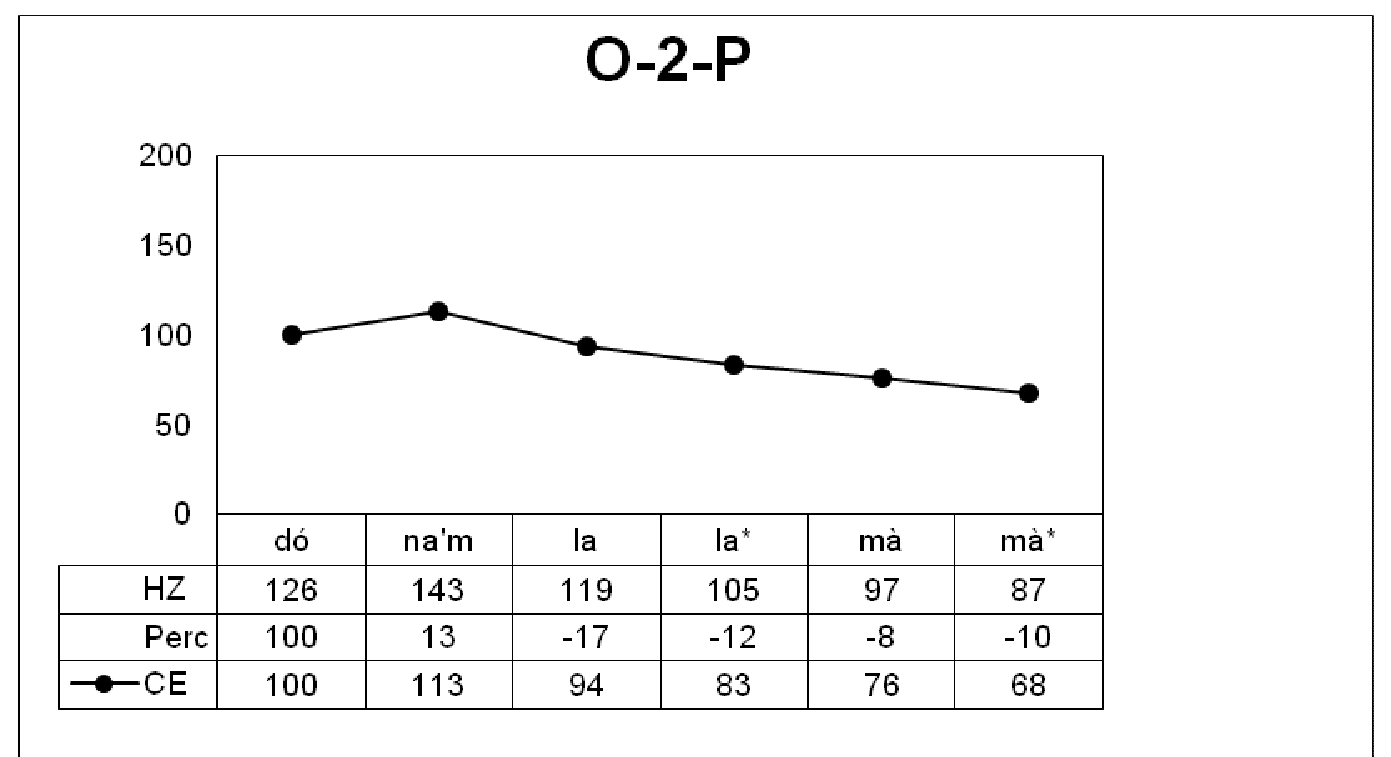

Figure 12. Original standardised utterance of the command: Dóna'm la ma (give me your hand)

Figure 12 shows the original utterance relating to a command.

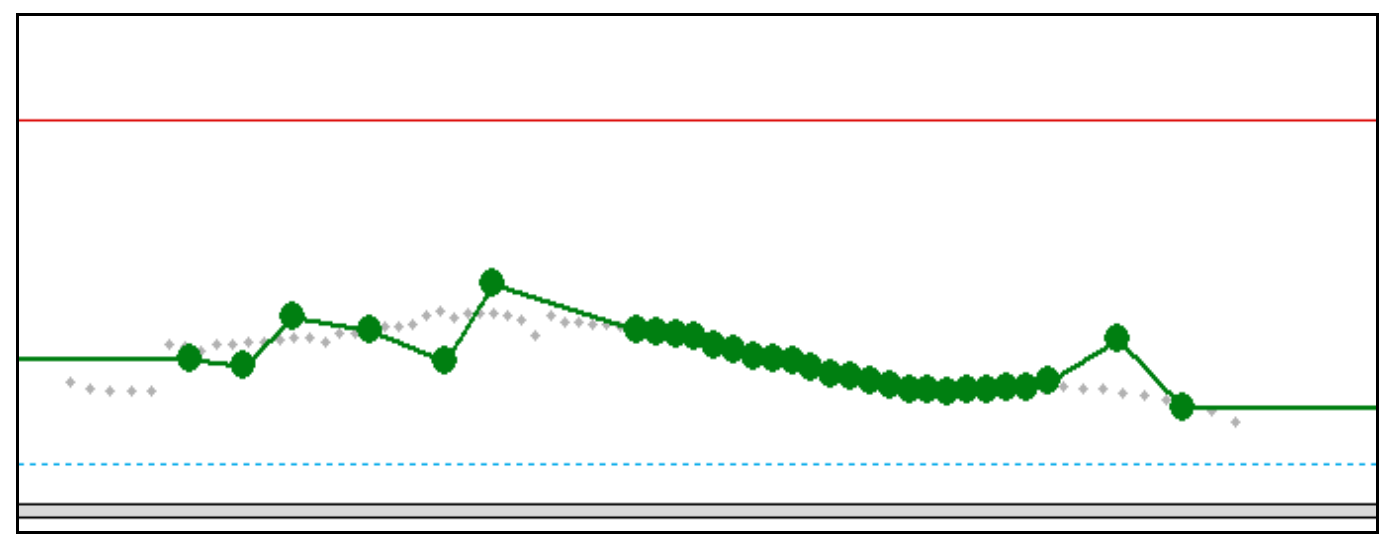

Figure 13. Manipulation of the same utterance with internal inflections and circumflex end

Figure 13 shows the combined manipulation of the same original utterance. As can be seen, two rising internal inflections have been introduced in the initial tonal segments and a

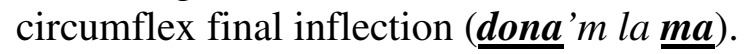




\subsubsection{Results of the perceptive phase}

The participants in the experiment (listeners) determined the changes in meaning that the modifications of the manipulated melodic characteristics conveyed, responding to the following questions:

\begin{tabular}{|l|l|l|}
\hline \multicolumn{1}{|c|}{ for the insults: } & \multicolumn{1}{c|}{ for the commands: } & \multicolumn{1}{c|}{ for the confrontations: } \\
\hline $\begin{array}{l}\text { he/she is angry and doesn't } \\
\text { want to offend }\end{array}$ & $\begin{array}{l}\text { it's a command given with } \\
\text { authority }\end{array}$ & $\begin{array}{l}\text { he/she seems to be looking for } \\
\text { confrontation }\end{array}$ \\
\hline $\begin{array}{l}\text { it's clear that he/she doesn't } \\
\text { want to offend }\end{array}$ & $\begin{array}{l}\text { more than a command it sounds } \\
\text { like a request }\end{array}$ & $\begin{array}{l}\text { he/she seems to be looking for } \\
\text { cooperation }\end{array}$ \\
\hline
\end{tabular}

Table 1 shows the total percentages of correct answers to the original utterances. We expected the original utterances to be perceived as impolite and the manipulated ones as attenuators. As hypothesised, the insults, commands and confrontations were perceived as such with high levels of correct responses.

\begin{tabular}{|c|c|}
\hline & \\
\hline CODIS ORIGINALS & PERCENTATGES D'ENCERT \\
\hline I-3-A & 96,2 \\
\hline O-2-P & 73,5 \\
\hline C-1-A & 69,8 \\
\hline I-4-A & 96,2 \\
\hline O-1-A & 45,2 \\
\hline C-6-A & 67,9 \\
\hline I-2-P & 41,5 \\
\hline O-1-P & 60,3 \\
\hline C-2-P & 84,9 \\
\hline O-3-P & 56,6 \\
\hline C-3-P & 75,4 \\
\hline
\end{tabular}

Table 1. Total percentages of correct responses to the original utterances (impolite)

In Table 2 we can see the percentages of correct responses to the simple manipulations; those with one characteristic manipulated:

- IFI corresponds to a final inflection manipulation introducing a final interrogative, with a rising percentage of over $70 \%$

- IFD is the same but with a falling final inflection

- IFS is the same but with a suspended end, with a rising percentage of no more than $40 \%$

- $\quad I F C$ corresponds to a circumflex rising-falling final inflection

- EP refers to the manipulations of a single word, emphasising it with a circumflex inflection in the tonic vowel

- II refers to the manipulation that introduces inflections in the internal tonic vowels of the utterance, leaving the final inflection in tact, and

- PA corresponds to the manipulation that modified the prominence of vowels, in this case removing the prominence of the tonics and introducing atonics. 


\begin{tabular}{|c|c|}
\hline \multicolumn{2}{|c|}{$\left.\right|^{\mid ⿴ 囗 十}$} \\
\hline CODIS MANIPULACIÓ SENZILLA & PERCENTATGES D'ENCERT \\
\hline I.F.I & 96,2 \\
\hline I.F.D. & 43,3 \\
\hline E.P & 83 \\
\hline I.F.S & 60,3 \\
\hline I.I & 28,3 \\
\hline P.A & 67,9 \\
\hline I.F.C & 41,5 \\
\hline
\end{tabular}

Table 2. Total percentages of correct responses to the simple manipulations

As we can see, the melodic characteristics that lead to the perception of the utterance as being more of an attenuator are: interrogative final inflections, suspended final inflections, word emphasis and prominence on atonic vowels. Surprisingly, there were no polite utterances in our corpus that used interrogative melody as an attenuating characteristic. However, the results of the perceptive tests are very clear. They are similarly so for the other melodic characteristics we added in our experiment because they are relevant for Spanish (circumflex internal and final inflections): it appears that in Catalan they do not convey this mitigating value.

Finally, below is the table of percentages of utterances with combined manipulations (see Table 3):

- Internal inflections (II) plus circumflex (IFC) and suspended (IFS) final inflections

- Prominence on atonics (PA) plus circumflex (IFC), suspended (IFS) and falling (IFD) final inflections

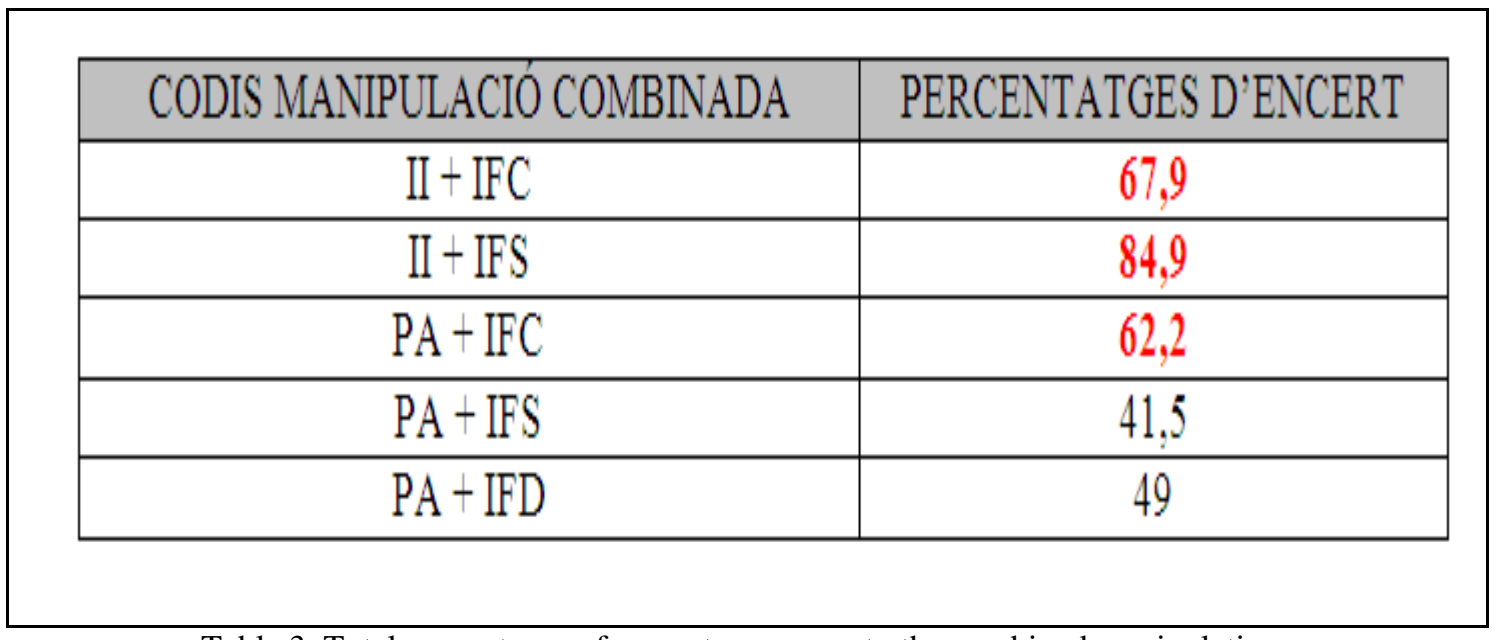

Table 3. Total percentages of correct responses to the combined manipulations

As we can see, the percentage of correct responses is high with regard to the simple manipulations of one characteristic, particularly in the case of the circumflex and suspended final inflections together with internal inflections. These characteristics alone do not provide an mitigating value, but combined they are very effective. 


\section{CONCLUSIONS}

From the acoustic description of the corpus and its subsequent experimental validation in the perceptive phase, we can conclude that the most successful melodic characteristics of politeness attenuators for Catalan (capable of converting commands, for example, into requests or confrontation into cooperation) are, in order of effectiveness:

1. Interrogative final inflection

2. Word emphasis with circumflex inflection

3. Combination of internal inflections with suspended final inflection

4. Combination of internal inflections with circumflex final inflection

5. Prominence of atonic vowels (simple or combined with circumflex final inflection)

6. Suspended final inflection

The results therefore, allow us to determine that in Catalan there is a set of well-defined melodic characteristics for expressing politeness attenuators. This set of melodic characteristics make up something similar to an intonation code, including the following:

- characteristics of linguistic intonation: /+interrogative/ and /+suspended/ contours, with a pragmatic value of politeness (and not of question or doubt, for example), and

- characteristics of paralinguistic intonation: in emphatic intonations, whose characteristics occupy the margins of dispersion of the /+emphatic/ contour.

Also, some of these melodic characteristics could characterise the melodic profile ${ }^{14}$ of other dialects or languages. Devís (in print), for example, shows how the prelinguistic intonation of Brazilian Portuguese can be understood, from Spanish, as a polite intonation, when in reality it is a neutral intonation in the language. Therefore, a Brazilian speaking Spanish (with his/her characteristic idiomatic accent) would be considered a very polite speaker to Spanish listeners, because the characteristics of his/her melodic profile coincide in the main part with polite characteristics in Spanish.

Another relevant conclusion of this study is that, essentially, the intonation codes of politeness for Catalan and peninsular Spanish are very close. The characteristics that provide a high level of attenuation in Spanish are (see Devís, 2011):

1. combination of internal inflections with a suspended final inflection

2. combination of internal inflections with a circumflex final inflection

3. combination of a prominence of atonics with a suspended final inflection

4. combination of internal inflections with an interrogative final inflection

5. combination of a prominence of atonics with a circumflex final inflection

To an extent, the code of politeness attenuators for Spanish and Catalan are culturally shared codes. The introduction in the perceptive tests of characteristics identified for Spanish that had not been observed in the acoustic phase for Catalan (the interrogative final inflections and the internal inflections), and their validation as attenuator characteristics also for Catalan, allow use to conclude that these are not two clearly differentiated idiomatic codes, but something along the lines of a single culturally shared code.

\footnotetext{
${ }^{14}$ The concept of "melodic profile" was established in a previous study (Cantero \& Devís, 2011) to refer to the melodic characteristics that define the prelinguistic intonation of "dialect", "idiomatic" and "foreign accents".
} 
The melodic characteristics of politeness attenuators do not form part of the linguistic code of the language (which in intonation would be exclusively phonologic characteristics ${ }^{15}$ ) but of the paralinguistic codes, shared not by all speakers of the language but by a community of specific speech.

It is unlikely that all speakers of the language mark politeness in the same way, or obey the same code (particularly among speakers of distant dialectal varieties). However, we can say that the politeness attenuator is part of a level of analysis of intonation that is close to constituting a stable or semi-stable code ${ }^{16}$ : socially and culturally shared, very close to the linguistic code (in that it allows a direct inter-comprehension), yet not specific to the language but to the speaking community.

In short, it is likely that there are "semi-stable" cultural codes, socially shared, that are useful for all speakers of Catalan and Spanish, close to what would be the linguistic codes of use, but which exceed strictly idiomatic limits. This would be a characteristic of languages that are permanently in contact.

It must be said that the melodic characteristics established in our research could be used as didactic models in language teaching, particularly as a foreign language: for beginners, to implement the oral comprehension also from cultural parameters; for advanced levels, to implement these typical speech characteristics in the development of oral abilities in production and interaction.

Furthermore, this research confirms the importance of working with a robust intonation analysis method that combines the extraction of acoustic data, clearly establishing the tonal segments, with its standardisation in relative values to provide a melody clean of irrelevant values (or "micromelodic variations"), and which allows the results to be validated by perceptive experiment tests.

This is probably the best path to progressively fill the theme gap in the pragmatic functions of intonation and, above all, to obtain an overall and integrated knowledge of the prosodic phenomenology that increasingly allows the understanding of the phenomena that intervene in oral communication and its didactic transposition.

\section{BIBLIOGRAPHIC REFERENCES}

Álvarez, Aexandra \& Blondet, María Alejandra. 2003. Cortesía y prosodia: un estudio de la frase cortés en el español de Mérida (Venezuela). In Pedro Martín Butragueño \& Esther Herrera (eds.), La tonía. Dimensiones fonéticas y fonológicas, 319-330. México: El Colegio de México.

Astruc, Lluïsa. 2008. Cortesía y entonación: las interrogativas absolutas en catalán. Revista de Letras 7. 41-53.

\footnotetext{
${ }^{15}$ In Cantero (2002) two types of intonation characteristics were defined: melodic characteristics (which are very specific, phonetic characteristics) and phonologic characteristics (which are merely opposing, abstract characteristics).

${ }^{16}$ See Cantero and Mateo (2011).
} 
Briz, Antonio \& Grupo Val.Es.Co. 2002. Corpus de conversaciones coloquiales. Anejo de la Revista Oralia. Madrid: Arcolibros.

Briz, Antonio \& Hidalgo Antonio. 2008. Marcadores discursivos y prosodia: observaciones sobre su papel modalizador atenuante. In Antonio Briz, et al. (eds.), Cortesía y conversación: de lo escrito a lo oral. III Coloquio Internacional del programa EDICE. http//:www.edice.org/descargas/3coloquioEDICE.pdf, 390-409.

Brown, Penelope \& Levinson Stephen C. 1987 [1978]. Politeness. Some universals in language usage. Cambridge University Press.

Cantero Serena, Francisco José. 1999. Análisis melódico del habla: principios teóricos y procedimientos, Actas del I Congreso de Fonética Experimental, Tarragona, 127-133.

Cantero Serena, Francisco José. 2002. Teoría y análisis de la entonación. Barcelona: Edicions de la Universitat de Barcelona.

Cantero Serena, Francisco José \& Font-Rotchés, Dolors. 2007. Entonación del español peninsular en habla espontánea: patrones melódicos y márgenes de dispersión, Moenia 13. 6992.

Cantero Serena, Francisco José \& Devís Herraiz, Empar. 2011. Análisis melódico de la interlengua. In Antonio Hidalgo et al. (eds.), El estudio de la prosodia en España en el S. XXI: perspectivas y ámbitos. Anejo de Quaderns de Filologia, 285-299. Universidad de Valencia.

Cantero Serena, Francisco José \& Miguel Mateo. 2011. Análisis melódico del habla: complejidad y entonación en el discurso. Oralia 14. 105-127.

Calsamiglia, Helena \& Tusón, Amparo. 2002. Las cosas del decir. Manual de Análisis del Discurso. Barcelona: Ariel Lingüística.

Devís Herraiz, Empar. 2011. La entonación de (des)cortesía en el español coloquial. Phonica 7. 36-79.

Devís Herraiz, Empar. in press. Entonación de cortesía involuntaria en el español hablado por brasileños. In Enrique Huelva (coord.), Estudos do Espanhol: lingüística, ensino e tradução. Brasilia/Sao Paulo: Pontes.

Font-Rotchés, Dolors. 2006. Corpus oral de parla espontània. Gràfics i arxius de veu. Biblioteca Phonica, 4. http://www.ub.es/lfa

Font-Rotchés, Dolors. 2007. L'entonació del català. Barcelona: Publicacions de l'Abadia de Montserrat.

Font-Rotchés, Dolors. 2009. Models d'entonació per a l'ensenyament del català. In Devís Herraiz, Empar \& Lídia Carol (eds.), Studi Catalani: Suoni e Parole, 83-102. Bolonya: Bononia University Press.

Haverkate, Henk. 1994. La cortesía verbal, Madrid: Gredos. 
Hidalgo, Antonio. 2001. Modalidad oracional y entonación. Notas sobre el funcionamiento pragmático de los rasgos suprasegmentales en la conversación. Moenia 7. 271-292.

Hidalgo, Antonio. 2006. La expresión de cortesía (atenuación) en español hablado: marcas y recursos prosódicos para su reconocimiento en la conversación coloquial. In Milka Villayandre (ed.), Actas del XXXV Simposio Internacional de la SEL, 958-979. León: Universidad de León.

Hidalgo, Antonio. 2007. Sobre algunos recursos fónicos del español y su proyección sociopragmática: atenuación y cortesía en la conversación coloquial. Quaderns de Filologia, Estudis Lingüístics 12. 129-142.

Hidalgo, Antonio. 2009. Modalización (des)cortés y prosodia: estado de la cuestión en el ámbito hispánico. Boletín de Filología de la Universidad de Chile XLIV/1. 161-195.

Lakoff, Robin Tomach. 1973. The logic of politeness; or minding your p's and q's, In Papers from the seventh regional meeting of the Chicago Linguistic Society, 292-305. Chicago: University Press.

Leech, Greoffrey. 1983. Principles of Pragmatics. London: Longman.

Nadeu, Marianna. 2008. The contribution of tonal scaling to the perception of politeness in Catalan. Barcelona: Universitat Pompeu Fabra. Research paper. http://prosodia.upf.edu/home/arxiu/tesis/master/tesina_nadeu.pdf

Nadeu, Marianna \& Pilar Prieto. 2011. Pitch range, gestural information, and perceived politeness in Catalan. In Journal of Pragmatics, vol. 43, Issue 3. 841-854.

Orozco, Leonor. 2008. Peticiones corteses y factores prosódicos. In Esther Herrera \& Pedro Martín Butragueño (eds.), Fonología Instrumental. Patrones fónicos y variación, 335-355. México: El colegio de México.

Payà, Marta, 2003. Politeness strategies in spoken Catalan: when prosodic and non prosodic elements don't match. Paper presented at the 6th NWCL International Conference: Prosody and Pragmatics, Preston (United Kingdom), November 15.

Payrató, Lluis. 1988. Català col.loquial. Valencia: Universitat de València.

Quilis, Antonio. 1988. Fonética Acústica de la lengua española. Madrid: Gredos.

Quilis, Antonio. 1993. Tratado de fonética y fonología españolas. Madrid: Gredos.

Roldán, Yasna. 2000. Correlatos acústicos de actos de habla atenuados del español de Chile. Onomazein 5. 107-118.

VV.AA. 2009. Análisis Melódico del Habla (AMH): 1999-2009. Biblioteca Phonica 10. www.ub.es/lfa 
Waltereit, Richard. 2005. La polifonía prosódica: Copiar un patrón entonativo. Revista Internacional de Lingüística Iberoamericana III-2. 137-150. 